\title{
CHILDREN IN CONFLICT WITH THE LAW IN THE BUREAU OF JAIL MANAGEMENT AND PENOLOGY AND PAG-ASA (HOPE) YOUTH CENTER IN ILIGAN CITY
}

\section{Perla P. Palomares}

\author{
MSU-Iligan Institute of Technology, Iligan City \\ Email: perla.palomares@g.msuiit.edu.ph
}

DOI: https://doi.org/10.18196/jgpp.5295

Article Info

Article history:

Received 21 Apr 2018

Revised 21 May 2018

Accepted 30 Jun 2018

\section{ABSTRACT}

This paper examined the experiences of children in conflict with the law (CICL) in the light of the lower-class-based theories of delinquency and labeling theory. Information on the current circumstances of the youth offender in the local context should prove useful as basis of concrete recommendations for policy decisions and courses of action for those concerned with children's welfare. The same information are vital for agencies and stakeholders in the five pillars of the justice system such as the law enforcement, the prosecution, the court, the penal system and the community. The study focused on the Tipanoy Jail under the BJMP and the Pag-asa (Hope) Youth Centre, the detention and rehabilitation centre of lligan City. The study covered a total of two semesters. The Lower-Class-Based Theory of Delinquency and the Labelling Theory provided the framework of this study. These theories explicate why youth offenders seem dominant in the lower-class sector of the population and how devastating the effects of labelling on them as individuals. Data were gathered from a sample of $15 \mathrm{CICL}$ and 15 non-CICL. Key informants from the DSWD, PNP, BJMP, RTC as well as parents of CICL were also involved. Personal interview, questionnaire, FGDs and case studies were utilized in data collection In turn, these were analyzed qualitatively whenever necessary and applicable, frequencies and percentages were used and data were displayed in tables and graph. Recommendations were offered based on findings. The findings are as follows: theorized factors such as overcrowding, poor housing, house ownership and type of home (broken home) were found to have influenced the commission of crimes, while migration status, employment status of father and mother were found to have nothing to do with commission of crimes

\footnotetext{
Keywords:

delinquency; children; youth offenders; crime; restorative justice.
}

\begin{abstract}
ABSTRAK
Makalah ini mengkaji pengalaman anak-anak yang berkonflik dengan hukum (CICL) dalam teori teori kenakalan dan pelabelan berdasarkan kelas yang lebih rendah. Informasi tentang keadaan saat ini dari pelaku remaja dalam konteks lokal harus terbukti berguna sebagai dasar rekomendasi konkrit untuk keputusan kebijakan dan program tindakan bagi mereka yang
\end{abstract}


peduli dengan kesejahteraan anak-anak. Informasi yang sama sangat penting bagi lembaga dan pemangku kepentingan dalam lima pilar sistem peradilan seperti penegakan hukum, penuntutan, pengadilan, sistem pemasyarakatan dan masyarakat. Studi ini berfokus pada Penjara Tipanoy di bawah BJMP dan Pusat Pemuda (Harapan), pusat detensi dan rehabilitasi Iligan City. Penelitian ini mencakup total dua semester. Teori Kenakalan Berbasis Kelas Bawah dan Teori Pelabelan menyediakan kerangka kerja dari penelitian ini. Teori-teori ini menjelaskan mengapa pelanggar remaja tampak dominan di sektor kelas bawah dari populasi dan bagaimana menghancurkan efek pelabelan pada mereka sebagai individu. Data dikumpulkan dari sampel $15 \mathrm{CICL}$ dan 15 non-CICL. Informan kunci dari DSWD, PNP, BJMP, RTC serta orang tua CICL juga terlibat. Wawancara pribadi, kuesioner, FGD dan studi kasus digunakan dalam pengumpulan data. Pada gilirannya, ini dianalisis secara kualitatif kapan pun diperlukan dan berlaku, frekuensi dan persentase digunakan dan data ditampilkan dalam tabel dan grafik. Rekomendasi diberikan berdasarkan temuan. Temuan-temuan tersebut adalah sebagai berikut: faktorfaktor berteori seperti kepadatan penduduk, perumahan yang buruk, kepemilikan rumah dan jenis rumah (broken home) ditemukan telah mempengaruhi tindakan kejahatan, sementara status migrasi, status pekerjaan ayah dan ibu ditemukan tidak memiliki apa-apa. harus dilakukan dengan komisi kejahatan

\section{INTRODUCTION}

This paper delves into a conflict between and among individuals and the state. It focuses on the experiences of children in conflict with the law which in this research is also termed as youth offenders vis-à-vis the different stages of the juvenile justice system mandated by Republic Act 9344 otherwise known as Comprehensive Juvenile Justice and Welfare System in the light of the "Lower-ClassBased Theories of Delinquency" (Shoemaker, 1990; Shaw and McKay, 1992; Lander 1994) and "Labeling Theory" (Shoemaker, 1990; Tannenbaum, 1938; Thrasher, 1936).

A person is viewed as a product of the surroundings, and his/her shortcomings indicate failure of the system of socialization, the socialization agents and the socio-cultural institutions that shape behavior. For this reason, criminal justice, in particular for the 
children in conflict with the law, has shifted from a purely punitive stance to restorative justice. This shift takes into account the welfare of the youth offenders and the interest and protection of the victim and the community. Delinquency as in the case of the CICL is overwhelmingly a lower-class, male phenomenon (Shoemaker, 1990). This means that juvenile delinquents are concentrated / dominated by male, working class sector of the juvenile population. Males usually stay outside of the home not only due to overcrowding and poor housing conditions but also because by nature males were said to have preferred to leave home in search of male identity in street gangs. In cases of households headed by single mothers, boys tend to go out in search of male role model as their homes do not have fathers with whom to identify; thus they become more prone to committing street offenses. Being with "one-sex peer units" the needs and behaviors that develop are consistent with the predominant values and norms of street gangs and they either become criminals, drug dependents, robbers, snatchers and youth offenders (Miller, 1996).

Lower-class-based theories posit that delinquency is concentrated in the "lower class", as measured by a variety of economic and social factors. Social class membership is associated with social values and lifestyles. The lower class child is likely to be taught that behavior should be spontaneous and aggressive, that values should be focused on the present with very little emphasis on long-range planning (Net Industries, 2011; Shoemaker, 1990:117). Criminal behavior is learned from the social environment, especially with gang members. Deviant motives and justification come from lower class values. Overcrowding, poor housing, low rates of home ownership, recent migration, unemployment, underemployment and broken homes are among the factors and attributes in the social environment that have been observed to be associated with commission of offenses of the youth. 
14 Another explanation may have something to do with the offender's initial encounter with the law enforcement which does the labeling. Labeling theory posits that the deviant is one to whom the label (e. g. thief) has successfully been applied (Becker, 1963:9). By extension, the CICL, given a label, form a distorted impression of himself and an identity that he/she gets from the treatment by law enforcers. Labeling contends that biased, discriminatory factors operate in the juvenile justice system, especially in terms of race, sex, social class or types of offense of juvenile suspects or dependents. Thus, experts like Frederick Thrasher, Frank Tannembaun and Edwin Lement argued that labeling someone as delinquent (CICL) can result in the person becoming the very thing he is described as being. Together with this corresponding role, as the stigma that the label gives may cause the CICL to become more criminal than before (Save the Children UK, 2004: Shoemaker, 1990).

Information on the current circumstances of the youth offender in the local context should prove useful as basis of concrete recommendations for policy decisions and courses of action for those concerned with children's welfare, particularly the welfare and development agencies and stakeholders in the five pillars of the justice system such as the law enforcement, the prosecution, the court, the penal system and the community.

In essence, RA 9344 provides that the State, recognizing the role of children and youth in nation building, shall protect their interests through measures that ensure the observance of international standards of child protection. In the case of CICL, the State shall apply the principles of restorative justice in all its laws, policies and programs. Accordingly, restorative justice system requires that the victim and the offender should agree to undergo together a process of mediation in the community. The goal of the process is to restore harmonious relations in the community. In order to restore 
peace and harmony, the offender expresses remorse for the harm done and makes some form of reparation to the victim in the presence of the barangay officials (Barangay Captain or the LupongTagapamayapa, barangay peace keeping committee).

The Children in Conflict with the Law (CICL) in Iligan City are the subjects of this study. Specifically, the objectives are the following: (1) to determine if the following theorized socio-economic factors of overcrowding, poor housing, home ownership, migration status, unemployment, and type of home influence the children to commit offenses; (2) to verify if the same socio-economic factors (overcrowding, poor housing, home ownership, migration status, unemployment, and type of home) relate to or have some bearing to the type and severity of alleged crimes committed by CICL; and, (3) to contrast CICL from Non-CICL in terms of their self-concept.

The implementation of the Juvenile Justice System is as an application of restorative justice otherwise called as diversion which involves processes and procedures that aim to prevent the case of the youth offenders from getting into the formal criminal justice system (Save the Children-UK, 2004).

\section{Statement of the Problem}

This is a study on the children in conflict with the law (CICL) in Iligan City who are under the auspices of the restorative justice system as mandated by the Republic Act 9344. Specifically, the study aims to answer the following questions:

1. What are the usual offenses committed by the children in conflict with the law who are taken care of by the Bureau of Jail Management and Penology and Pag-asa (Hope) Youth Center in Iligan City?

2. Which of the following theorized factors namely overcrowding, poor housing, home ownership, migration 
status, unemployment, may relate with the commission of crimes by the children?

3. What are the experiences of the children in each of the following stages of the justice system which are apprehension, detention and adjudication?

\section{Research Design}

This paper is a descriptive-evaluative study. It focused on the situation of the children in conflict with the law who are specifically housed at the Tipanoy Jail or BJMP and the Pag-asa Youth Center which is the rehabilitation center of the City Social Welfare and Development Office. As a qualitative study this used the descriptive approach in investigating the situation of children who are in conflict with the law particularly their experiences in the various stages of the juvenile justice system.

\section{Research Locale}

The study was conducted in Iligan City, focusing on the Tipanoy Jail under the Bureau of Jail Management and Penology (BJMP) and the Pag-asa Youth Center under the management of the City Social Welfare and Development (CSWD). Presently, the City has 44 barangays with a total population of 322,821 persons as of May 1, 2010. It has a total land area of 813.37 square kilometers, making it as one of the 10 largest cities in the Philippines (Census of Population in Iligan City, 2007).

Iligan city is not only rich in natural resources and industries but it is also the home of a mix of cultures, Maranaos of Lanao del Sur, Higaonons of Bukidnon and many settlers and migrants from other parts of the country.

\section{Participants of the Research}


This is a study of the experiences of the children in conflict with the law in Iligan City, and the unit of analysis is the child. Data on children's socio-demographic and economic background, and their experiences at the different stages of the juvenile justice system were gathered mainly through interviews. The participants which include the key informants were chosen through purposive sampling.

\section{Data-gathering Instruments and Procedure}

This study used a triangulation method in gathering of data, 3 instruments were used: interview guide, FGD guide and observation guide. After permission had been secured from the Office of the City Mayor and the CSWD, initial visits to Tipanoy Jail and the Youth Center were done. Then interview schedules were arranged as well as the FGD sessions.

\section{Statistical Instruments and Mode of Analysis}

For the quantitative data, this study uses non-parametric measures because of the small sample size utilized in this research. This is intended not to violate the normality assumptions of parametric measures. For measures of relationships whose variables are nominal this research uses Symmetric Lambda. Then Kolmogovov-Smirnov (K-S) for one nominal variable and one interval variable and Fishers's Exact Test for nominal variables which are dichotomous, in which one cell value is very small.

However, for the qualitative data which were obtained through the interview, FGD and actual observation, this study used narratives of the participants in analyzing them. These narratives and observation results are categorized into themes and integrate them to the data obtained from the survey.

\section{FINDINGS AND ANALYSIS OF DATA}


The usual offenses committed by the youth offenders who are taken cared of by the bureau of jail management and penology and pag-asa (hope) youth center in iligan city.

The results of the study disclose that the usual offenses committed by the youth offenders are slight physical injury, rugby sniffing, slight destruction of properties, smoking in public places, in possession of bladed instrument, rape, drug use, theft, robbery, and murder. The key informant said that these offenses could be categorized further into misdemeanor and felony. Slight physical injury, rugby sniffing, slight destruction of properties, smoking in public places and possession of bladed instrument belong to misdemeanor while the rest are classified as felony.

Theorized factors which relate with the commission of crimes by the children

As previously theorized, there were six major socio-economic factors namely: overcrowding, poor housing, home ownership, migration status, employment status, and type of home (e. g. intact or broken). These factors are discussed as they may have influenced the commission of the crime.

Overcrowding and commission of a crime. Overcrowding as measured by number of persons per room is shown in Table 1 . All non-CICL (100\%) are depicted to be in homes where the environment is not crowded, described as normal as there are only between one to four occupants in a room, and none of them was accused of a crime. Among the CICL 5 out of 15 (33.3\%) lived or used to live in normal households and were accused of a crime. 
Table 1. Cross Tabulation Showing Relationship between Overcrowding and Type of Respondents Accused of Crime

\begin{tabular}{|l|c|c|c|c|c|c|}
\hline \multirow{2}{*}{ Number of Persons Per Room } & \multicolumn{4}{|c|}{ Types of Respondent } & \multicolumn{2}{|c|}{ Total } \\
\cline { 2 - 7 } & \multicolumn{2}{|c|}{ Non-CICL } & \multicolumn{2}{|c|}{ CICL } & & \\
\cline { 2 - 7 } & F & $\%$ & F & $\%$ & F & $\%$ \\
\hline Normal (1-4) & 15 & 100.0 & 5 & 33.3 & 20 & 66.7 \\
\hline Overcrowded (5+) & 0 & .0 & 10 & 66.7 & 10 & 33.3 \\
\hline Total & 15 & $100 \%$ & 15 & $100 \%$ & 30 & $100 \%$ \\
\hline
\end{tabular}

A vast majority of CICL come from houses that are overcrowded. Not one of the non-CICL comes from overcrowded houses.

Overcrowding in the household has implications on competition over claim for space, and over meager resources. The tendency is for the children to stay outside of the house, into the streets. This behavior tends to relieve, rather than irritate; the parents. Child socialization therefore is done more by the peer group, and less by the parents. The CICL therefore are exposed to occasions for crime.

Poor housing and commission of a crime. Quality of housing is measured by the type of materials a house is made of. All nonCICL (100\%) lived in houses made of strong materials, while all CICL (100\%) lived in houses made of weak materials. as shown in Table 2.

Table 2. Cross Tabulation Showing the Relationship between Poor Housing and Type of Respondents Accused of Crime

\begin{tabular}{|c|c|c|c|}
\hline \multirow[b]{2}{*}{ Housing Materials } & \multicolumn{2}{|c|}{ Types of Respondent } & Total \\
\hline & Non-CICL & CICL & \\
\hline
\end{tabular}




\begin{tabular}{|l|c|c|c|c|c|c|}
\hline & $\mathrm{F}$ & $\%$ & $\mathrm{~F}$ & $\%$ & $\mathrm{~F}$ & $\%$ \\
\hline Weak & 0 & 0.0 & 15 & 100.0 & 15 & 50.0 \\
\hline Strong & 15 & 100.0 & 0 & 0.0 & 15 & 50.0 \\
\hline Total & 15 & $100 \%$ & 15 & $100 \%$ & 30 & $100 \%$ \\
\hline
\end{tabular}

A distinct contrast is discernible in Table 2. All non-CICL come from houses that are of good quality; while all CICL come from houses made of poor quality materials.

Putting together the implications of Table 1 and 2 and subsequently Table 3 (house ownership), one perceives that overcrowding, and poor housing are three considerations for the child leaving home.

House ownership and commission of crime. As depicted in Table 3, all non-CICL (100\%) lived in the house and lot that the parents own; only 4 out of 13 CICL (30.8\%) lived in the house and lot that parents own. Two gave no answer whose parents did not own a house.

Table 3. Cross Tabulation Showing Relationship between House Ownership and Type of Respondents Accused of Crime.

\begin{tabular}{|l|c|c|c|c|c|c|}
\hline \multirow{2}{*}{ House Ownership } & \multicolumn{4}{|c|}{ Types of Respondent } & \multicolumn{2}{c|}{ Total } \\
\cline { 2 - 7 } & \multicolumn{2}{|c|}{ Non-CICL } & \multicolumn{2}{c|}{ CICL } & & \\
\cline { 2 - 7 } & $\mathrm{F}$ & $\%$ & $\mathrm{~F}$ & $\%$ & $\mathrm{~F}$ & $\%$ \\
\hline Own house and lot & 15 & 100.0 & 4 & 30.8 & 19 & 67.9 \\
\hline Own house rent lot & 0 & 0.0 & 7 & 53.8 & 7 & 25.0 \\
\hline Rent house & 0 & 0.0 & 2 & 15.4 & 2 & 7.1 \\
\hline Total & 15 & $100 \%$ & 13 & $100 \%$ & 28 & $100 \%$ \\
\hline
\end{tabular}

Migration status and commission of a crime. Table 4 indicates that the same number of non-CICL and CICL were migrants which 
imply that migration status is not related to the commission of an offense

Table 4. Cross Tabulation Showing Relationship between Migration Status and Type of Respondents Accused of Crime

\begin{tabular}{|c|c|c|c|c|c|c|}
\hline \multirow{3}{*}{ Are you migrant } & \multicolumn{4}{|c|}{ Types of Respondent } & \multicolumn{2}{|c|}{ Total } \\
\hline & \multicolumn{2}{|c|}{ Non-CICL } & \multicolumn{2}{|c|}{ CICL } & & \\
\hline & $\mathrm{F}$ & $\%$ & $\mathrm{~F}$ & $\%$ & $\mathrm{~F}$ & $\%$ \\
\hline No & 8 & 53.3 & 8 & 53.3 & 16 & 53.3 \\
\hline Yes & 7 & 46.7 & 7 & 46.7 & 14 & 46.7 \\
\hline Total & 15 & $100 \%$ & 15 & $100 \%$ & 30 & $100 \%$ \\
\hline
\end{tabular}

Employment status of father and commission of crime. Table 5 revealed that while all non-CICL (100\%) have fathers who are working, most CICL (86.7\%) also have fathers who are working too. Therefore, employment of father does not lead to the development of CICL.

Table 5. Cross Tabulation Showing Relationship between Employment Status of Father and Type of Respondents Accused of Crime

\begin{tabular}{|c|c|c|}
\hline & Types of Respondent & Total \\
\hline
\end{tabular}




\begin{tabular}{|l|c|c|c|c|c|c|}
\hline \multirow{2}{*}{ Employment of Father } & \multicolumn{2}{|c|}{ Non-CICL } & \multicolumn{2}{|c|}{ CICL } & & \\
\cline { 2 - 8 } & $\mathrm{F}$ & $\%$ & $\mathrm{~F}$ & $\%$ & $\mathrm{~F}$ & $\%$ \\
\hline Unemployed & 0 & 0.0 & 2 & 13.3 & 2 & 6.7 \\
\hline Employed & 15 & 100.0 & 13 & 86.7 & 28 & 93.3 \\
\hline Total & 15 & $100 \%$ & 15 & $100 \%$ & 30 & $100 \%$ \\
\hline
\end{tabular}

Employment status of mother and commission of a crime. It can be gleaned from Table 6 , that while 80 percent of non-CICL have mothers who are working, most CICL (66.7\%) also have mothers who are working. Thus, employment status of mother does not lead to the development of a $\operatorname{CICL}\left(X 1^{2}=1.065\right.$, n. s. at $\left.\propto .05\right)$.

Table 6. Cross Tabulation Showing Relationship between Employment Status

Of Mother and Type of Respondents Accused of Crime

\begin{tabular}{|l|c|c|c|c|c|c|}
\hline \multirow{2}{*}{ Employment of Mother } & \multicolumn{4}{|c|}{ Types of Respondent } & \multicolumn{2}{c|}{ Total } \\
\cline { 2 - 7 } & \multicolumn{2}{|c|}{ Non-CICL } & \multicolumn{2}{|c|}{ CICL } & & \\
\cline { 2 - 7 } & $\mathrm{F}$ & $\%$ & $\mathrm{~F}$ & $\%$ & $\mathrm{~F}$ & $\%$ \\
\hline Unemployed & 3 & 20.0 & 5 & 33.3 & 8 & 26.7 \\
\hline Employed & 12 & 80.0 & 10 & 66.7 & 22 & 73.3 \\
\hline Total & 15 & $100 \%$ & 15 & $100 \%$ & 30 & $100 \%$ \\
\hline
\end{tabular}

$X 1^{2}=1.065$, not significant at $\propto .05$

Type of home and commission of a crime. Type of home in this study categorized homes of CICL or not in terms of whether they are intact (all members or at least both parents lived together) or broken. Parents of non-CICL are depicted to be living together in Table 7. Among CICL however only 8 out of 13 (61.5\%) have parents who lived together. This means some 38.5 percent who were accused of certain offenses come from broken homes. This somehow proved that type of home (broken home) leads to the development of 
a CICL. Table 7 further revealed that one parent was already dead, while the other one is unknown to one particular child.

Table 7. Cross Tabulation Showing Relationship between Type of Home and Type of Respondent Accused of Crime

\begin{tabular}{|l|c|c|c|c|c|c|}
\hline \multirow{2}{*}{ Do parents live together } & \multicolumn{4}{|c|}{ Types of Respondent } & \multicolumn{2}{c|}{ Total } \\
\cline { 2 - 7 } & \multicolumn{2}{|c|}{ Non-CICL } & \multicolumn{2}{|c|}{ CICL } & & \\
\cline { 2 - 7 } & F & $\%$ & F & $\%$ & F & $\%$ \\
\hline No & 0 & 0.0 & 5 & 38.5 & 5 & 17.9 \\
\hline Yes & 15 & 100.0 & 8 & 61.5 & 23 & 82.1 \\
\hline Total & 15 & $100 \%$ & 13 & $100 \%$ & 28 & $100 \%$ \\
\hline
\end{tabular}

Most of the tables in this section of the paper have values that do not allow statistical tests. But the pattern especially across Table 3, 4, 5, 7, and 8 shows that indeed the CICL tend to come from households living in poor condition. The pattern tends to support the lower-class-based theory of delinquency which posits that youth offenders come from poor families

Do socio-economic factors, namely: overcrowding, poor housing, house ownership, migration status, employment status, and type of home relate to the type of alleged crimes in terms of severity.

This section examines whether the theorized socio-economic factors and attributes are predictors of the severity of crimes. In the previous section, it was shown that poverty seemed to be associated with the commission of crime among the youth.

Theoretically, it may be said that crimes are meticulously planned out of need, then the more needy may be expected to commit more severe ( i. e. more financially rewarding) crimes like 
robbery. This section explores whether severity of crime is associated with poorer household circumstances.

Table 8 reveals that 15 CICL or (100\%) have been accused of crime. These crimes were categorized into misdemeanour and felony. Misdemeanour is a minor crime involving for example an offense against property, which in this study included sniffing industrial solvent, snatching, petty theft and possession or sale of bladed instrument. Felony, on the other hand, is a major crime involving an offense against person like homicide, murder, robbery with murder and gunrunning. Table 8 further indicates that 60 percent of CICL were accused of misdemeanour, while 40 percent were accused of felony.

Table 8. Crime CICL Accused of

\begin{tabular}{|l|c|c|}
\hline \multicolumn{1}{|c|}{ Type of Crime } & Frequency & Percentage \\
\hline Misdemeanour & 9 & 60.0 \\
\hline Felony & 6 & 40.0 \\
\hline Total & 15 & $100 \%$ \\
\hline
\end{tabular}

When respondents were asked if the above-mentioned crimes were first offense ever committed, majority of CICL (93.3\%) responded in the affirmative (first offender) while only 6.7 percent answered in the negative (second offender) as Table 9 indicated. This means that a great majority of the CICL were first offenders. Only one was a repeat offender.

Table 9. Is This the First Offense Ever Committed?

\begin{tabular}{|c|c|c|}
\hline $\begin{array}{c}\text { Category of } \\
\text { Commission }\end{array}$ & Frequency & Percentage \\
\hline First - Yes & 14 & 93.3 \\
\hline Second - No & 1 & 6.7 \\
\hline Total & 15 & $100 \%$ \\
\hline
\end{tabular}


Table 10. Cross Tabulation Showing Relationship between Type of Offender and Type of Crime Accused of

\begin{tabular}{|l|c|c|c|}
\hline Type of Offender & \multicolumn{2}{|c|}{ Type of Offense } & Total \\
\hline & Misdemeanour & Felony & \\
\hline First Offender & 8 & 6 & 14 \\
\hline Second Offender & 1 & 0 & 1 \\
\hline Total & 9 & 6 & 15 \\
\hline
\end{tabular}

Overcrowding and Type of Crime. Table 11 reveals that CICL from normal and overcrowded households have the same share of felony cases (33.3\%). Overcrowding therefore is not associated with severity of crime.

Table 11. Cross Tabulation Showing Relationship between Overcrowding and Type of Crime

\begin{tabular}{|c|c|c|c|c|c|c|}
\hline \multirow{3}{*}{$\begin{array}{c}\text { Number of Persons } \\
\text { Per Room }\end{array}$} & \multicolumn{4}{|c|}{ Types of Crime } & \multicolumn{2}{|c|}{ Total } \\
\hline & \multicolumn{2}{|c|}{ Felony } & \multicolumn{2}{|c|}{ Misdemeanor } & & \\
\hline & $\mathrm{F}$ & $\%$ & $\mathrm{~F}$ & $\%$ & $\mathrm{~F}$ & $\%$ \\
\hline (1-4) Normal & 2 & 33.3 & 3 & 33.3 & 5 & 33.3 \\
\hline (5+) Overcrowded & 4 & 66.7 & 6 & 66.7 & 10 & 66.7 \\
\hline Total & 6 & $100 \%$ & 9 & $100 \%$ & 15 & $100 \%$ \\
\hline
\end{tabular}

$X_{1}^{2}=0.0$, not significant

Poor housing and type of crime. Among the CICL accused of felony some 83.3 percent live or used to live in houses made of weak materials while 16.7 percent were from houses with strong materials. The difference in percentage however was not statistically significant at the .05 level, Kendall's Tau-C (-.196, not significant at $\propto .338)$ as shown in Table 12. However, two gave no answer or did not live in a house. 
Table 12. Cross Tabulation Showing Relationship between Poor Housing and

Type of Crime

\begin{tabular}{|c|c|c|c|c|c|c|}
\hline \multirow{3}{*}{ Housing materials } & \multicolumn{4}{|c|}{ Types of Crime } & \multicolumn{2}{|c|}{ Total } \\
\hline & \multicolumn{2}{|c|}{ Felony } & \multicolumn{2}{|c|}{ Misdemeanor } & & \\
\hline & $\mathrm{F}$ & $\%$ & $\mathrm{~F}$ & $\%$ & $\mathrm{~F}$ & $\%$ \\
\hline Weak & 5 & 83.3 & 6 & 85.7 & 11 & 84.6 \\
\hline Strong & 1 & 16.7 & 1 & 14.3 & 2 & 15.4 \\
\hline Total & 6 & $100 \%$ & 7 & $100 \%$ & 13 & $100 \%$ \\
\hline
\end{tabular}

Kendall's Tau-C $=-.196$, not significant (n.s.) at the .05 level, 2 tailed test.

House ownership and type of crime. House ownership is shown not to be associated with type of offense accused of CICL as the computed Lambda value of .33 is found to be not significant at the .05 level (one-tailed test). Two CICL gave no answer or did not own a house.

Table 13. Cross Tabulation Showing Relationship between House Ownership and

Type of Crime

\begin{tabular}{|l|c|c|c|c|c|c|}
\hline \multirow{2}{*}{ House ownership } & \multicolumn{4}{|c|}{ Types of Crime } & \multicolumn{2}{c|}{ Total } \\
\cline { 2 - 8 } & \multicolumn{2}{|c|}{ Felony } & \multicolumn{2}{c|}{$\begin{array}{c}\text { Misdemeanou } \\
\text { r }\end{array}$} & & \\
\cline { 2 - 8 } & $\mathrm{F}$ & $\%$ & $\mathrm{~F}$ & $\%$ & $\mathrm{~F}$ & $\%$ \\
\hline Own house and lot & 1 & 16.7 & 3 & 42.9 & 4 & 30.8 \\
\hline Own house rent lot & 3 & 50.0 & 4 & 57.1 & 7 & 53.8 \\
\hline Rent house & 2 & 33.3 & 0 & 0.0 & 2 & 15.4 \\
\hline Total & 6 & $100 \%$ & 7 & $100 \%$ & 13 & $100 \%$ \\
\hline
\end{tabular}


Migration Status and Type of Crime. While some 50 percent of migrants were accused of felony against the (50\%) of non-migrants, the difference is not statistically significant at the .05 level, Fisher's Exact Test (=.62).

Table 14. Cross Tabulation Showing Relationship between Migration Status and

Type of Crime

\begin{tabular}{|c|c|c|c|c|c|c|}
\hline \multirow{3}{*}{ Type of migrant } & \multicolumn{4}{|c|}{ Types of Crime } & \multicolumn{2}{|c|}{ Total } \\
\hline & \multicolumn{2}{|r|}{ Felony } & \multicolumn{2}{|c|}{ Misdemeanour } & & \\
\hline & $\mathrm{F}$ & $\%$ & $\mathrm{~F}$ & $\%$ & $\mathrm{~F}$ & $\%$ \\
\hline No & 3 & 50.0 & 5 & 55.6 & 8 & 53.3 \\
\hline Yes & 3 & 50.0 & 4 & 44.4 & 7 & 46.7 \\
\hline Total & 6 & $100 \%$ & 9 & $100 \%$ & 15 & $100 \%$ \\
\hline
\end{tabular}

Employment Status of Father and Type of Crime. The computed value of the Fisher's Exact Test of.34 means that the employment status of father is not associated with type of crime committed.

Table 15. Cross Tabulation Showing the Relationship between Employment Status of Father and Type of Crime

\begin{tabular}{|c|c|c|c|c|c|c|}
\hline \multirow{3}{*}{$\begin{array}{l}\text { Employment } \\
\text { status of father }\end{array}$} & \multicolumn{4}{|c|}{ Types of Crime } & \multicolumn{2}{|c|}{ Total } \\
\hline & \multicolumn{2}{|c|}{ Felony } & \multicolumn{2}{|c|}{$\begin{array}{l}\text { Misdemean } \\
\text { our }\end{array}$} & & \\
\hline & $\mathrm{F}$ & $\%$ & $\mathrm{~F}$ & $\%$ & $\mathrm{~F}$ & $\%$ \\
\hline Unemployed & 0 & 0.0 & 2 & 22.2 & 2 & 13.3 \\
\hline Employed & 6 & 100.0 & 7 & 77.8 & 13 & 86.7 \\
\hline Total & 6 & $100 \%$ & 9 & $100 \%$ & 15 & $100 \%$ \\
\hline
\end{tabular}


Employment Status of Mother and Type of Crime. A computed Fisher's Exact Test value of .29 again means that the employment status of mother is not associated with type of crime committed.

Table 16. Cross Tabulation Showing the Relationship between Employment Status of Mother and Type of Crime

\begin{tabular}{|c|c|c|c|c|c|c|}
\hline \multirow{3}{*}{$\begin{array}{c}\text { Employment status } \\
\text { of mother }\end{array}$} & \multicolumn{4}{|c|}{ Types of Crime } & \multicolumn{2}{|c|}{ Total } \\
\hline & \multicolumn{2}{|r|}{ Felony } & \multicolumn{2}{|c|}{ Misdemeanour } & & \\
\hline & $\mathrm{F}$ & $\%$ & $\mathrm{~F}$ & $\%$ & $\mathrm{~F}$ & $\%$ \\
\hline Unemployed & 3 & 50.0 & 2 & 22.2 & 5 & 33.3 \\
\hline Employed & 3 & 50.0 & 7 & 77.8 & 10 & 66.7 \\
\hline Total & 6 & $100 \%$ & 9 & $100 \%$ & 15 & $100 \%$ \\
\hline
\end{tabular}

Type of home (broken home) and type of crime. Fisher's Exact Test on the two variables obtained a value of .56 which is not significant at the .05 level (2-tailed test), indicating that there is no relationship between type of home (broken home) and type of crime.

Table 17. Cross Tabulation Showing Relationship between Type of Home (Broken Home) and Type of Crime

\begin{tabular}{|l|c|c|c|c|c|c|}
\hline \multirow{2}{*}{$\begin{array}{c}\text { Type of Home } \\
\text { (broken home) }\end{array}$} & \multicolumn{4}{|c|}{ Types of Crime } & \multicolumn{2}{c|}{ Total } \\
\cline { 2 - 7 } & \multicolumn{2}{|c|}{ Felony } & \multicolumn{2}{c|}{ Misdemeanour } & & \\
\hline No & 1 & 20.0 & 4 & 50.0 & 5 & 38.5 \\
\hline Yes & 4 & 80.0 & 4 & 50.0 & 8 & 61.5 \\
\hline Total & 5 & $100 \%$ & 8 & $100 \%$ & 1 & $100 \%$ \\
\hline
\end{tabular}

Table 18 reflects a summary of the relationships between theorized socio-economic factors and attributes, and crime accused of 
at Alpha .05. As shown, there is no significant relationship between any of the theorized factors and attributes, and the type of crime to which CICL were accused of. In other words, the CICL come from poor households. But the poorer among them did not necessarily tend to commit more severe (i. e. more economically rewarding) crimes.

Table 18. Summary Table of Relationships between Theorized Factors and Type of Crime Accused of at Alpha .05

\begin{tabular}{|l|l|c|}
\hline \multicolumn{1}{|c|}{$\begin{array}{c}\text { Theorized Socio- } \\
\text { economic Factors }\end{array}$} & \multicolumn{1}{|c|}{ Relationship } & Significance \\
\hline Overcrowding & Chi square $=0$ & n. s. \\
\hline Poor housing & $\begin{array}{l}\text { Kendall's Tau-C }=\text { n. s. } \\
.196\end{array}$ & n. s. \\
\hline House ownership & Lambda =.33 & n. s. \\
\hline Migration Status & $\begin{array}{l}\text { Fisher's Exact Test }= \\
.62\end{array}$ & n. s. \\
\hline $\begin{array}{l}\text { Employment Status of } \\
\text { Father }\end{array}$ & $\begin{array}{l}\text { Fisher's Exact Test }= \\
.34\end{array}$ & n.s. \\
\hline $\begin{array}{l}\text { Employment Status of } \\
\text { Mother }\end{array}$ & $\begin{array}{l}\text { Fisher's Exact Test }= \\
.29\end{array}$ \\
\hline Type of home & $\begin{array}{l}\text { Fisher's Exact Test }= \\
.56\end{array}$ & n. s. \\
\hline
\end{tabular}

3. The Experiences of the Children in Each of the Following Stages of the Justice System, Namely: Apprehension, Detention, And Adjudication

Apprehension. This is the first stage of the juvenile process. The Philippine National Police (PNP), through its statutory power to arrest, investigate and detain child offenders is usually the first point 
156 of contact of the child (AKAP 1998: 45 and 48). The PNP particularly the Women and Children Protection Department (WCPD with its Children and Youth Relations Section (CYRS) is guided by the principle that children should be handled differently from adults. These guidelines include the following:

1.The child's constitutional rights should also be explained.

2. In the absence of a lawyer, a social worker should affix his or her signature to the statement given by the child.

3. When a criminal charge is filed by the complainant against the child, the case should be referred to a social worker.

4. The child's parents should be informed of the child's situation as soon as possible and must also be present when a statement is taken from the child.

5. The child, regardless of the absence of visible injury, should be immediately brought to a medical facility for physical and mental evaluation

Basing from the data nobody among the youth offenders admitted that he was caught in the act, nor committed the offense accused of him. However, 60 percent of the youth offenders said they were informed of the reasons of their arrest but majority of them said that they were not informed of their rights as stipulated in the guidelines mentioned above. A few even claimed that they were subjected to physical abuse while in custody of the police officer.

Detention: It must be recalled that a child could not be just detained immediately after arrest. It is in the law that alternative remedies must be exhausted as early as at the Katarungang Pambarangay. Whenever detention is necessary, a child will always be detained in youth detention homes established by local governments. The results reveal that the youth offenders were not aware of their rights to have a legal counsel but in the Pag-sa Youth Center parents; visitation is allowed, they are allowed to participate in pyscho-social 
activities, given food and are provided with facilities in their sleeping quarters.

Adjudication is the legal process of finally determining the innocence or guilt of persons accused of having infringed the penal code which is performed by the courts. But this happens only when cases cannot be settled amicably. There are also instances when some cases were already decided, but it took some time for release papers to be served. Accordingly, slow disposition of cases may be attributed to delays/postponement of trials due to the unavailability of minors' counsel, holidays, absence of witnesses and nonappearance of parties during scheduled hearings and congestion of cases in the family court.

\section{Summary, conclusion and recommendations}

This paper looks into an interpersonal conflict and focuses on the experiences of children in conflict with the law or youth offenders vis-à-vis the different stages of the juvenile justice system mandated by Republic Act 9344 otherwise known as Comprehensive Juvenile Justice and Welfare System in the light of the lower-class-based theories of delinquency and labelling theory.

This is a descriptive study on the experiences of youth offenders in the Bureau of Jail and Management and the Pag-asa Youth Center in Iligan City. This study uses triangulation method in data gathering: survey, FGD and actual observation. For the method of data analysis this used descriptive statistics for the quantitative data and narratives for the data obtained from the interview, FGD and actual observation.

\section{RESULTS AND DISCUSSION}

In Terms of Common Offenses. The results of the study disclose that the usual offenses committed by the youth offenders are 
15: slight physical injury, rugby sniffing, slight destruction of properties, smoking in public places, in possession of bladed instrument, rape, drug use, theft, robbery, and murder. These offenses could be categorized as misdemeanor and felony.

Theorized Factors in Association with the Commission of Offenses. Findings of the study revealed that the six major socioeconomic attributes theorized, overcrowding, poor housing, house ownership and type of home (broken home) were found to be associated with the commission of crimes. Migration statuses, employment status of father and of mother were found to have nothing to do with commission of crimes.

Theorized Factors and Type of Crime. All factors, namely overcrowding, poor housing, house ownership, migration status, employment status of father, employment status of mother and broken home were not found to have caused the commission of misdemeanor and felony of the participants. Findings of the study revealed that 14 out of $15 \mathrm{CICL}$ were first offenders and they were accused of both misdemeanour and felony. Of the six major socioeconomic attributes theorized, overcrowding, poor housing, house ownership and type of home (broken home) were found to be associated with the commission of crimes. Migration statuses, employment status of father and of mother were found to have nothing to do with commission of crimes.

The patterns across Table 1 to 7 show that indeed the CICL tend to come from household living in poor condition which tends to support the Lower-class Based Theory of Delinquency. Moreover, not a single factor which was theorized to influence the severity of crimes was found to be so, as all theorized factors did not obtain significant relationships with specific types of crimes such as misdemeanour and felony. 
The Experiences of Children in conflict with the Law at Different Stages of the Juvenile Justice System. The first stage of the juvenile justice system is apprehension. Based on the guidelines, the youth offenders were arrested generally along the guidelines except for some isolated cases. However, some youth offenders experienced (1) physically abuse; (2) there was no barangay intervention; (3) were not read or informed of their rights as accused children; and, (4) accused children were detained at the Police Station more than eight (8) hours. Apprehension or arrest of youth offenders was generally in accordance with laws and ordinances except for isolated cases. Youth offenders in the first place were informed of the reason of their arrest, the arresting officer was a police, there was no use of foul language and physical abuse was not that prevalent. But the youth offenders were not read/informed of their rights as accused. The youth offenders reported that they were brought to a medical facility for physical examination and their families were contacted by the police.

The second stage of the juvenile justice system is detention. Experiences of youth offenders at detention as expected were based on some guidelines as mandated by law except for some deviations. These deviations include the following: (1) Delayed processing of cases as indicated by the long detention of youth offenders and the number of court trials that many of the youth offenders have undergone. The longest detention time was 16 months. According to reports, there was a child who was forced to be transferred to the cell of the adults because "he had come of age." (2) Only few were visited by parents or guardians; and, (3) facilities and amenities provided at both detention centers were not enough.

The youth offenders were housed at the Pag-asa Youth Center while waiting for trial and decision from the courts. But for those offenders who, while waiting for court decision reached 18 years old, they were detained at the BJMP. Experiences at detention were not 
160 that bad as youth offenders had access to legal assistance, some were visited by parents, activities were undertaken by jail personnel and staff assigned in the youth center intended for the detainees. There are not many house rules to abide by and commission of violation to these house rules did not entail severe punishments. It was noted that officers used decent language in dealing with the detainees.

The third stage of the juvenile justice system is adjudication, which in this study, was the last experienced by the youth offenders at the Tipanoy Jail, while those at the Pag-asa Youth Center (there were three) had already undergone some post adjudication-rehabilitation activities. Majority of youth offenders are undergoing trial for several times. Findings reveal that a great majority of youth offenders are in the process of adjudication. The youth offenders at Pag-asa are still undergoing trial yet are also allowed to participate in rehabilitation and reintegration activities such as values formation sessions, skills training like gardening, plastic flower-making and livelihood.

Youth offenders come from household living in poor condition which shows support the Lower-class Based Theory of Delinquency.

\section{CONCLUSION}

The findings of this inquiry present a link with poverty and dysfunctional family to the children's vulnerability to commit offenses. The youth who are envisioned as future pillars of the country need an all-out support from the family who is the first institution responsible for their socialization process. A family who cannot nurture the children appropriately gives opportunity for other actors in the environment who may probably influence the development of their negative behavior towards oneself, to others, and the society at large. The vulnerability of the youth to be involved in various activities either legal or illegal due to the influences of peers and gangs pave the way to the commission of crimes. This is 
quite glaring in the case of the experiences of the participants of this research.

There was a slow pace and prolonged litigation process involving the youth offenders of this research. As opined by Larbi, G. A., (2000), "policy implementation, in the context of Public Administration, continues to be a problem because the judicial system is weak, inconsistent, and slow. The law may provide for the rule of exception or necessity, which then becomes the norm and defeats the intent of the original law. No procedures may exist for the making and enforcement of administrative laws". Larbi (2000) further pointed out that "legal reforms should be a high priority on government agenda if they are to bring about administrative reform and strengthen the rule of law. Judicial institutions also need strengthening to enhance the enforcement of laws. Likewise, more need to be done to inform citizens, the youth offenders in particular, about their rights and responsibilities under the law. There are still a handful of rights of the youth offenders which were violated by the government. The need to inform the rights of the accused upon capture is basic hence should not be compromised. Facilities in the correctional and youth centers should be provided under human conditions. However, this is not so in this research. Therefore, this practice contradicts the right to human dignity.

Nowadays, citizens in particular, are disdainful of the law because they see their government and its officials disregard it. Consequently, many individuals have chosen to defy the system. All of these efforts will not be successful unless the average citizen feels that the system is fair and just and the rules are clear and transparent. has been an integral part of this experience.

The delay in the legal process as experienced by the participants of this research could be construed as denying justice. Delaying justice tantamount to prolonging the agony of the parties involved in the crime. In particular, this indeed is violation to the 
162 rights of the accused to a speedy trial and speedy disposition of cases which are enshrined in the 1987 constitution of the Philippines particularly Article 111, section 14(on right to speedy trial) and VII, section 15, paragraph 1 (on speedy disposition of cases) of the fundamental law.

The study lends credence to lower-class-based theories of juvenile delinquency. The youth offenders come from poor households. Similarly, it can be said that social and economic life is "block-booked", that is, those who are poor also have low education, have low quality occupation, live in low quality and overcrowded housing units, and so on, and, are more likely to produce youth offenders. The opposite is true for those who are relatively rich. For this reason, the poor cannot afford a good lawyer and therefore are treated differentially by the justice system. The litigation process worked against the interest and violated the rights of the poor and the marginalized members of the society.

This practice does not jibe with the tenets of restorative justice system. The application of the juvenile justice system which is mirrored in the experiences of the youth offenders of this research is obviously a contradiction. It is shown in the research results that it is only the offenders who are the vey concern of the BJMP and the youth facility. However, the restorative justice policy is concerned with four sectors who are affected by the crime: the victim, the offender, their families and the community. Acceptance of the responsibilities of the offenders, repairing the harm, and doing no harm in the future are vital values that should be instilled among the offenders while they are still in the youth facility. This approach may deter the commission of future harm and provide a smooth transition for their eventual integration to the community.

One of the important pillars of the restorative justice or even the mainstream retributive justice of the state is the community. The community is a collection of individuals who have enduring 
relationships. While it is recognized that commission of crimes are violations of the law still the fact remains that crimes are also offenses against human relationships which is a key component of restorative justice.

In application to the concept of restorative justice the community is a potential source of information regarding illegal acts or any misdemeanor committed by children or any possible threats that these children may be capable of doing. Henceforth, these concerns could be acted upon immediately by the community stakeholders and may not escalate to crimes that require the usual litigation process in the court.

On a positive thought, the community has sets of values, morals and beliefs that are vital to the development of the positive behavior of the children. Community leaders, elders and other stakeholders need to showcase to the youth attitudes and behavior which are important in improving a peaceful community relation by utilizing peaceful methods of resolving conflict like dialogue, conferencing among families and mediation. Achieving restorative justice requires a cooperative process involving all stakeholders in the community. And since the institutionalization of the juvenile justice system mandated by Republic Act 9344 in the Philippines is marked by few lapses in its implementation, more reforms are still needed in order to appreciate the genuine meaning of restorative justice.

\section{REFERENCES}

Becker, H. S. (1963). Outsiders: Studies in the Sociology of Deviance. New York: Free Press.

Cohen, A.K. (1955). Delinquent Boys. New York: Free Press.

Cloward, Richard, A. and L. E. Ohlin (1960). Delinquency and Opportunity. New York: Free Press.

Etemadi, F. U., Li Ye, C. and Bermudez, C. Jr. (2004). Children in Conflict with the Law in Cebu: Profile and Experience with the Juvenile Justice Process._Quezon City Save The children UK. 
17 Feldman, D. (1969). Delinquency, Crime and Social Process. New York: Harper and Row.

Godttfredson, M. and Hirschi, T. (1990)._A General Theory of Crime. Stanford, CA: Stanford University Press.

Jonstone, R. I., (1975). Religion and Society in Interaction: The Sociology of Religion._Englewood Cliffs: Prentice-Hall.

Lander, B. (1954). Towards an Understanding of Juvenile Delinquency. New York: Columbia University Press.

Lowell, T. (1976). Community Development: A Network Approval in Adult Education. New York: Columbia University Press.

Miller, W. B. (1975). Violence by Youth Gangs and Youth Groups as a Crime Problem in Major American Cities._Washington, D. C.: United States Government Printing Press._Mortley, et al.,( 2003). Crime Justice and Punishment in Baldock Social Policy._( $3^{\text {rd }}$. ed.) Oxford: Oxford University Press.

Reckless, W. C. (1972). The Prevention of Juvenile Delinquency. Columbus: Ohio State University Press.

Save the Children - UK, (2004). Breaking Rules: Children in Conflict with the Law and the Juvenile Justice Process, The Experience in the Philippines. Quezon City: Save the Children UK.

Shaw, C. R. and H. D. McKay. (1994). Juvenile Delinquency and Urban Areas. Chicago: University Press.

Shoemaker, D. J. (1990). Theories of Delinquency. New York: Oxford University Press.

Steiner, et al., (1997). Violent Crime Paths in Incarcerated Juvenile: Psychological, Environmental, and Biological Factors. New York: New York Press.

Tannenbaum, F. (1938). Crime and the Community. New York: Ginn and Company.

Templa, et al., (2004). Understanding Children in Conflict with the Law: Contradictions on Victimization, Survivor Behavior and the Philippine Justice System. Quezon City: Save the Children UK.

Trinidad, et al.,(2006). Behind the Mask: Experiences of Children in Conflict with the Law from Rural and Non-Major Urban Areas. Makati

City: Plan Philippines 